\title{
In vitro Regeneration of Saussurea heteromalla (D. Don.) Hand-Mazz Using Auxins and Current Status in Galiyat Abbottabad
}

\author{
H. Mehreen ${ }^{1 *}$, J. Zafar ${ }^{1}$, G. Zishan ${ }^{2}$ \\ ${ }^{1}$ Department of Botany, Government Post Graduate College, Abbottabad, Pakistan \\ ${ }^{2}$ Hazara Agriculture Research Station, Abbottabad, Pakistan
}

Corresponding author E-mail: mehreenhameed856@gmail.com

Received: 03.09.2020. Accepted: 03.10.2020

\begin{abstract}
Current Status of Saussurea heteromalla was investigated in Galiyat areas of District Abbottabad, viz., Jahaffar, Seri, Beeran Gali, Banj, Haryala, Daryala Gali, Sarbhanna, Barriyan, Akhreela and Broangiala. Saussurea heteromalla was found common in Seri, Sarbhanna and Barriyan; endangered in Haryala, Jahaffar, Banj, Daryala Gali and Beeran Gali and absent in Akhreela and Broangiala. In vitro regeneration of Saussurea heteromalla (D. Don.) Hand-Mazz on MS media was conducted and shoots were developed on full strength MS medium supplemented with $1 \mathrm{mgL}^{-1} \mathrm{GA}$. The developed shoots were transferred for root induction to half strength MS medium fortified with various concentrations of Indole butyric acid (IBA) and a-Naphthalene acetic acid (NAA) i.e.

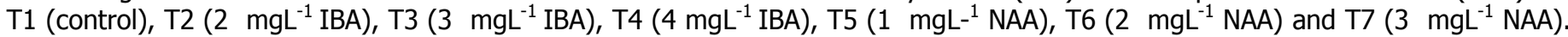
Maximum mean shoot length $(6.3 \mathrm{~cm})$, mean number of leaves (7), mean number of nodes (5.25); highest root emergence percentage $(71 \%)$, means root length $(1.5 \mathrm{~cm})$, mean number of roots $(3)$ and highest survival rate $(100 \%)$ was recorded in treatment T4. However, treatments T5 and T6 also seem to be effective for in vitro rooting of Saussurea heteromalla. Treatments T2, T3 and T7 showed minimum root growth. It was concluded that IBA at higher concentration is more effective for in vitro rooting and better shoot growth of Saussurea heteromalla whereas NAA also initiate rooting but at lower concentration.
\end{abstract}

Keywords: Saussurea heteromalla; Medicinal plants; In vitro regeneration; Current Status

\section{Introduction}

Saussurea heteromalla (D. Don.) Hand-Mazz is an endangered medicinal plant belongs to family Asteraceae (Compositae) locally known as Kali-Ziri. It is a tall perennial herb native to Western Himalayas, at altitudes of 550-4000m and found in open places. In Pakistan it is distributed in Baluchistan, Kurram, Punjab, Chitral, Swat, Hazara, Salt Range, Rawalpindi, Lahore, Murree and Pakistani Kashmir (Butola \& Samant, 2010). The leaves, roots, seeds and whole plant is reported to have medicinal value and have been used in the treatment of various ailments of humans and livestock such as nervous breakdown, liver problems, hysteria, cardiac troubles, carminative, febrifuge, antidote against horse bite, vitiligo, wounds, fever, colic and skin diseases (Quattrocchi, 2012; Butola \& Samant, 2010). Plant is reported to possess arctiin, arctigenin and chlorojanerin. Arctiin and arctigenin are reported to possess antiinflammatory activity while chlorojanerin is known to have anti-ulcer and anti-viral properties (Saklani et al., 2011).

There are only few literature reported about Status of Saussurea heteromalla in Pakistan such as Qureshi et al., (2008) reported that Saussurea heteromalla was common in Abbottabad District; Butola \& Samant, (2010) reported its Conservation Status was common overall in Pakistan; Khan et al., (2014) found its Status in Poonch Valley Azad Kashmir was endangered; Hussain et al., (2016) found it to be occasional in Rawalakot Azad Jammu and Kashmir (Pakistan) and Khalid \& Shah (2016) reported its Conservation Status was rare in Mohmand Agency, (FATA).

Habitat destruction, overgrazing and overexploitation by local herbalists due to its wide range of medicinal value have threatened its abundance even occurrence/existence. It is therefore necessary to take immediate step for rapid mass multiplication of this medicinally important plant species through tissue culture techniques, in order to save as well as to maintain sustainable amount of plant derived drugs. Nowadays, Plant tissue culture techniques have been increasingly applied for rapid mass multiplication and conservation of rare, endangered and other economically important plants. The plants propagated through tissue culture techniques have been used for reintroduction to recover the populations of endangered plants in their wild habitats, thus it save plants from extinction (Sen \& Sharma, 1991). In vitro regeneration of Saussurea heteromalla has not been done so far. Therefore the prime objective of present study was to develop a suitable lab protocol for successful in vitro rooting and growth of Saussurea heteromalla on MS medium supplemented with different concentrations of auxins. Beside this present research work was also conducted to determine the Current Status of Saussurea heteromalla in Galiyat areas of District Abbottabad by using IUCN Conservation Status Criteria via questionnaire.

\section{Materials and Methods}

The present study was carried out in Potato Tissue Culture Laboratory at Hazara Agriculture Research Station (HARS), Abbottabad in 2019. 


\section{Field trips and data enumeration}

In order to determine the Current Status of Saussurea heteromalla in Galiyat areas of District Abbottabad, 10 areas were visied viz Jahaffar, Seri, Beeran Gali, Banj, Haryala, Daryala Gali, Sarbhanna, Barriyan, Akhreela and Broangiala. Different information about the Current status of plant was recorded via questionnaire from local inhabitants. Besides local inhabitant, information about the Current status of Saussurea heteromalla was also recorded by our own field visits and general observation technique. Fresh plants of Saussurea heteromalla were identified through identification key 'Flora of Pakistan' (Nazimuddin and Qaiser, 1983).

\section{Preparation and sterilization of culture medium}

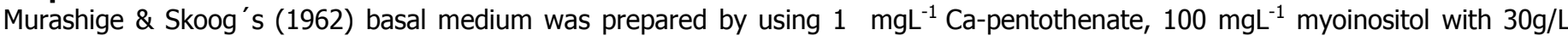
sucrose, $6 \mathrm{~g} / \mathrm{L}$ agar and $1 \mathrm{mgL}^{-1} \mathrm{GA3}$. $\mathrm{pH}$ of the medium was adjusted to 5.8 by adding few drops of either $1 \mathrm{~N} \mathrm{NaOH}$ or $1 \mathrm{~N} \mathrm{HCL}$ solution prior to autoclaving. These test tubes were sterilized in an autoclave at $121^{\circ} \mathrm{C}$ and 15 psi pressure for $15-20$ minutes.

\section{Surface sterilization and inoculation of explants}

For in vitro study nodal segments explants $(0.5-1.0 \mathrm{~cm})$ were excised and thoroughly washed with tap water for 2-3 times. After that they were surface sterilized with $0.1 \%(\mathrm{w} / \mathrm{v})$ Mercuric chloride $\left(\mathrm{HgCl}_{2}\right)$ solution for 1 minute followed by washing thrice with sterilized distilled water. Then nodal segments were treated with $0.1 \%(\mathrm{w} / \mathrm{v})$ Antibiotic (Penicillin) solution for 1 minute followed by three times washing with sterilized distilled water. Finally explants were treated with $0.3 \%(\mathrm{w} / \mathrm{v})$ Carbendazim solution for 2 minutes and then rinsed thrice with sterilized distilled water to remove final traces of sterilant prior to inoculation. In order to expose fresh tissues nodal segments containing axillary buds were trimmed at both ends and then inoculated aseptically on artificial nutrient medium in laminar flow cabinet. After inoculation the cultured test tubes were maintained at $20 \pm 2^{\circ} \mathrm{C}$ in growth chamber for 16 hours light and 8 hours dark periods.

\section{Rooting medium}

For in vitro rooting MS Half Strength medium was prepared and divided into 7 portions. Each portion represent a treatment containing a different concentration of Indole butyric acid (IBA) and a-Naphthalene acetic acid (NAA); and labeled as T1 (0), T2 (2

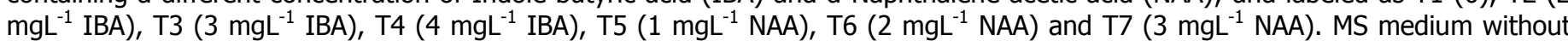
auxins served as controlled (T1).

\section{Data collection}

Data were recorded after 1 week interval from each test tube. Data regarding root induction was observed for 3 weeks. The data parameters were Shoot emergence, Shoot length, Number of nodes, Number of leaves; Root emergence, Number of roots, Root Length; Survival and Death Rate.

\section{Statistical analysis}

All the experiments were carried out in a Complete Randomized Design (CRD) and the data were analyzed by using computer software Statistix 8.1. Means were compared by using Least Significance Difference (LSD) test at 5\% probability level.

\section{Results and Discussion}

\section{Current status of Saussurea heteromalla}

Present research work demonstrated that Saussurea heteromalla was common in 3 localities i.e., Seri, Sarbhanna and Barriyan, the reasons for its abundance may be because of suitable soil, climatic and topographic conditions. In Haryala, Jahaffar, Banj, Daryala Gali and Beeran Gali it is recorded as being endangered (Table 1), this might be because of habitat destruction, overgrazing and to some extent overexploitation. In Akhreela and Broangiala, Saussurea heteromalla is absent; as both these localities are found at high altitude and also these are rocky areas. According to IUCN Red List Categories and Criteria, (2001) a species is said to be an endangered when its population has declined between $50 \%$ and $70 \%$ and cause of the decline may either be unknown or known. This definition fit into 5 localities of Galiyat, hence overall Status of Saussurea heteromalla in Galiyat is endangered.

Table 1. Current Status of Saussurea heteromalla in Lower Galiyat Areas.

\begin{tabular}{|c|c|c|c|c|}
\hline \multirow{2}{*}{$\begin{array}{l}\text { S. } \\
\text { No }\end{array}$} & \multirow[t]{2}{*}{ Localities } & \multicolumn{3}{|c|}{ Current Status (\%) } \\
\hline & & Common & Endangered & Absent \\
\hline 1 & Jahaffar & $40 a b c$ & $60 \mathrm{a}$ & $0 \mathrm{~b}$ \\
\hline 2 & Seri & $80 \mathrm{a}$ & $40 \mathrm{a}$ & $0 \mathrm{~b}$ \\
\hline 3 & Haryala & 20 bc & 80 a & $0 \mathrm{~b}$ \\
\hline 4 & Daryala Gali & 20 bc & $60 \mathrm{a}$ & $20 \mathrm{a}$ \\
\hline 5 & Banj & $40 a b c$ & $60 \mathrm{a}$ & $0 \mathrm{~b}$ \\
\hline 6 & Sarbhanna & 80 a & 20 a & $0 \mathrm{~b}$ \\
\hline 7 & Barriyan & $60 a b$ & $40 a$ & $0 \mathrm{~b}$ \\
\hline 8 & Beeran Gali & $40 a b c$ & 60 a & $0 \mathrm{~b}$ \\
\hline 9 & Akhreela & $0 \mathrm{c}$ & 20 a & $80 \mathrm{a}$ \\
\hline 10 & Broangiala & 20 bc & $20 \mathrm{a}$ & $60 \mathrm{a}$ \\
\hline
\end{tabular}

Means in a column followed by the same letters are not significantly different at $P \leq 0.05$.

\section{In vitro regeneration}

For shoot regeneration, nodal segments were inoculated on MS basal medium supplemented with 1 mgL-1 GA3. After 2 days of culturing shoot emergence were observed in all cultured segments (Figure 1). Data recorded after 1st week of culturing showed that mean shoot length was $2.31 \mathrm{~cm}$ with 2.89 mean numbers of leaves and 2.18 mean numbers of nodes (Figure 2). A significant increase was observed in mean shoot length $(5.1 \mathrm{~cm})$, mean numbers of leaves (5.25) and mean numbers of nodes (4.27) (Figure 3) after 2nd week of culturing. GA3 promote shoot elongation by stimulating cell division and elongation (Taiz \& Zeiger, 2002). 
Results showed that GA3 plays a vital role not only in shoot elongation but also significantly increased the number of nodes and leaves (Figure 3) which corroborates with the observation made by Rostami and Shahsava, (2012). George et al., (2008) reported that pre-treatment of plant material with GA3 enhances subsequent root formation on root-inducing medium.

Table 2. Rooting response after $1^{\text {st }}, 2^{\text {nd }}$ and $3^{\text {rd }}$ week of Sub-culturing on rooting medium.

\begin{tabular}{|c|c|c|c|c|c|c|c|c|c|}
\hline \multirow[b]{2}{*}{ Treatments } & \multicolumn{3}{|c|}{ Root Emergence \% } & \multicolumn{3}{|c|}{ Root Length (cm) } & \multicolumn{3}{|c|}{ No of Roots } \\
\hline & $1^{\text {st }}$ week & $2^{\text {nd }}$ week & $3^{\text {rd }}$ week & $1^{\text {st }}$ week & $2^{\text {nd }}$ week & $3^{\text {rd }}$ week & $1^{\text {st }}$ week & $2^{\text {nd }}$ week & $3^{\text {rd }}$ week \\
\hline $\mathrm{T}_{1}$ & $0 \mathrm{~b}$ & $0 \mathrm{~b}$ & $0 \mathrm{~b}$ & $0 \mathrm{a}$ & $0 \mathrm{a}$ & $0 \mathrm{~b}$ & $0 \mathrm{a}$ & $0 \mathrm{~b}$ & $0 \mathrm{~b}$ \\
\hline$T_{2}$ & $14 a b$ & $29 a b$ & $29 a b$ & $0.09 \mathrm{a}$ & $0.12 \mathrm{a}$ & $0.45 \mathrm{~b}$ & $0.14 \mathrm{a}$ & $0.29 \mathrm{~b}$ & $0.67 b$ \\
\hline$T_{3}$ & $14 a b$ & $29 a b$ & $43 a b$ & $0.1 \mathrm{a}$ & $0.21 \mathrm{a}$ & $0.73 \mathrm{~b}$ & $0.17 \mathrm{a}$ & $0.43 \mathrm{~b}$ & $0.83 \mathrm{~b}$ \\
\hline $\mathrm{T}_{4}$ & 57 a & $57 \mathrm{a}$ & $71 a$ & $0.57 \mathrm{a}$ & $0.75 \mathrm{a}$ & $1.5 \mathrm{a}$ & $0.57 \mathrm{a}$ & $1.5 \mathrm{a}$ & $3 a$ \\
\hline $\mathrm{T}_{5}$ & $29 a b$ & $29 a b$ & $50 a b$ & $0.4 \mathrm{a}$ & $0.67 \mathrm{a}$ & $1.2 \mathrm{ab}$ & $0.33 a$ & $0.57 \mathrm{~b}$ & $1.2 \mathrm{~b}$ \\
\hline $\mathrm{T}_{6}$ & $29 a b$ & $29 a b$ & $57 a b$ & $0.21 \mathrm{a}$ & $0.41 \mathrm{a}$ & $0.97 b$ & $0.43 a$ & $0.71 \mathrm{~b}$ & $1.43 a b$ \\
\hline $\mathrm{T}_{7}$ & $14 a b$ & $29 a b$ & $43 a b$ & $0.12 \mathrm{a}$ & $0.35 \mathrm{a}$ & $0.79 \mathrm{~b}$ & $0.29 \mathrm{a}$ & $0.43 \mathrm{~b}$ & $0.89 \mathrm{~b}$ \\
\hline
\end{tabular}

Means in a column followed by the same letters are not significantly different at $P \leq 0.05$.

Table 3. Survival and Death Percentage of regenerated plantlets of Saussurea heteromalla after $3^{\text {rd }}$ week of sub-culturing on rooting medium.

\begin{tabular}{ccc}
\hline Treatments & $\begin{array}{c}\text { Survival Rate } \\
(\%)\end{array}$ & $\begin{array}{c}\text { Death Rate } \\
\mathbf{( \% )}\end{array}$ \\
$\mathrm{T}_{1}$ & $0 \mathrm{c}$ & $100 \mathrm{a}$ \\
$\mathrm{T}_{2}$ & $57 \mathrm{~b}$ & $43 \mathrm{~b}$ \\
$\mathrm{~T}_{3}$ & $86 \mathrm{ab}$ & $14 \mathrm{bc}$ \\
$\mathrm{T}_{4}$ & $100 \mathrm{a}$ & $0 \mathrm{c}$ \\
$\mathrm{T}_{5}$ & $100 \mathrm{a}$ & $0 \mathrm{c}$ \\
$\mathrm{T}_{6}$ & $100 \mathrm{a}$ & $0 \mathrm{c}$ \\
$\mathrm{T}_{7}$ & $86 \mathrm{ab}$ & $14 \mathrm{bc}$
\end{tabular}

Means in a column followed by the same letters are not significantly different at $P \leq 0.05$.

Table 4. Comparison of Growth rate of Saussurea heteromalla after $5^{\text {th }}$ week of culturing.

\begin{tabular}{cccc}
\hline Treatments & $\begin{array}{c}\text { Shoot Length } \\
(\mathbf{c m})\end{array}$ & $\begin{array}{c}\text { No of } \\
\text { Leaves } \\
0 \mathrm{c}\end{array}$ & $\begin{array}{c}\text { No of } \\
\text { Nodes }\end{array}$ \\
$\mathrm{T}_{1}$ & $0.89 \mathrm{~b}$ & $4.67 \mathrm{~b}$ & $4.47 \mathrm{~b}$ \\
$\mathrm{~T}_{2}$ & $5 \mathrm{ab}$ & $5.12 \mathrm{ab}$ & $4.77 \mathrm{ab}$ \\
$\mathrm{T}_{3}$ & $6.3 \mathrm{a}$ & $7 \mathrm{a}$ & $5.25 \mathrm{a}$ \\
$\mathrm{T}_{4}$ & $6 \mathrm{a}$ & $6.43 \mathrm{ab}$ & $5.14 \mathrm{a}$ \\
$\mathrm{T}_{5}$ & $5.7 \mathrm{a}$ & $6.14 \mathrm{ab}$ & $5 \mathrm{a}$ \\
$\mathrm{T}_{6}$ & $5.13 \mathrm{ab}$ & $5.29 \mathrm{ab}$ & $4.83 \mathrm{ab}$ \\
$\mathrm{T}_{7}$ & &
\end{tabular}

Means in a column followed by the same letters are not significantly different at $P \leq 0.05$.

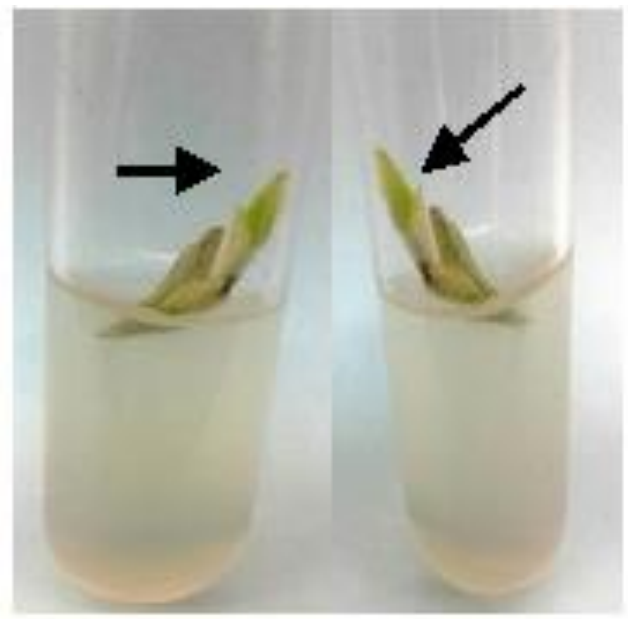

Figure 1. Shoot emergence in the cultured nodal segment of Saussurea heteromalla after 2 days of culturing.

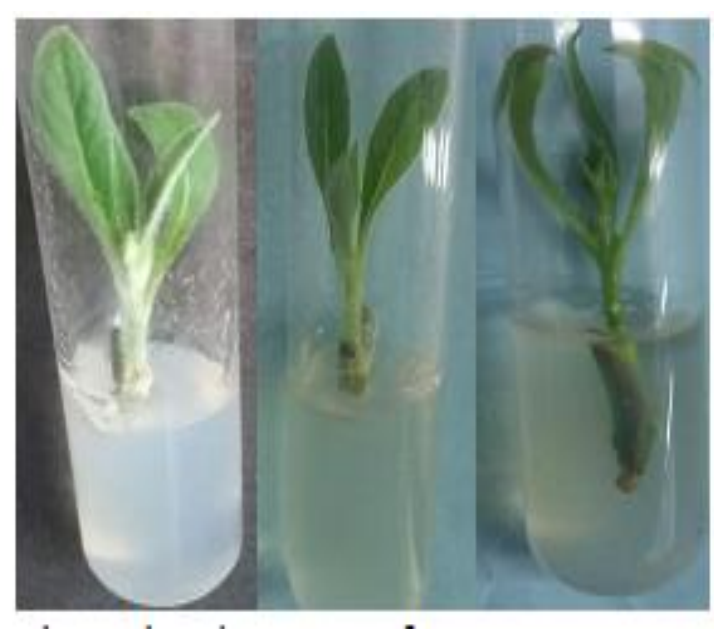

Figure 2. Shoot development of Saussurea heteromalla after 1st week of culturing. 


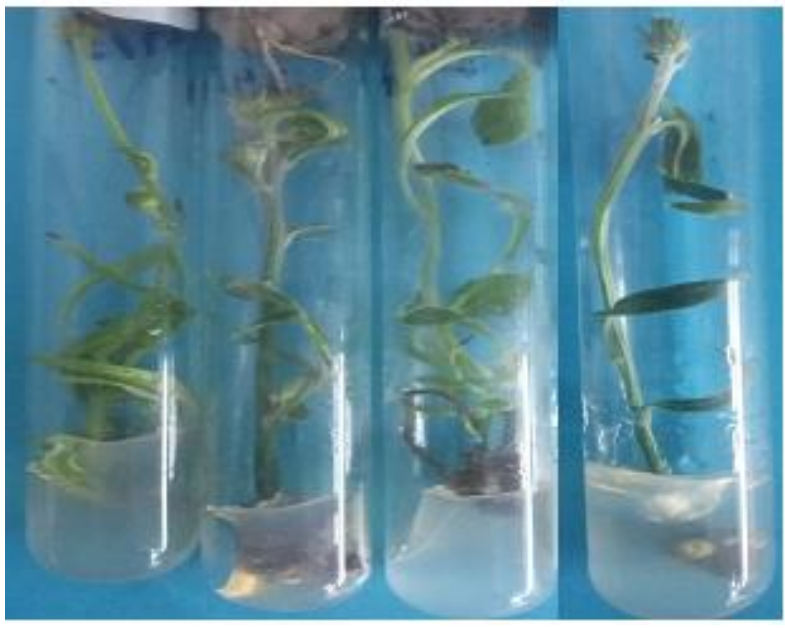

Figure 3. Shoot development of Saussurea heteromalla after 2nd week of culturing.

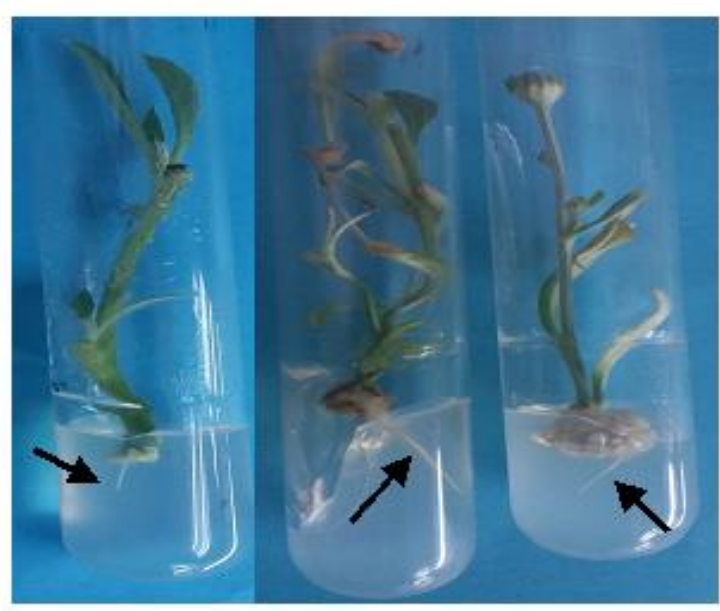

Figure 4. Root emergence in the regenerated shoot of Saussurea heteromalla.

\section{Root emergence percentage}

After 3rd week of sub-culturing on various rooting media root induction was observed in all treatments except control (T1) which did not develop any root emergence due to lack of auxins (Table 2) (Figure 4) and according to George, (1993) auxin plays a major role in root formation and development. Highest root emergence percentage was recorded in treatment T4 (4 mgL $\mathrm{m}^{-1}$ of IBA) which corroborates with the early findings of Grigoriadou et al., (2011) on Achillea occulta. Exogenously added IBA under in vitro conditions may induce changes in peroxidase, IAA oxidase activity and phenolic contents allowing the establishment of the favorable endogenous hormone balance for root initiation in excised shoots (Qaddoury and Amssa, 2004). In treatments T5 (1 mgL ${ }^{-1}$ of NAA) and T6 (2 mgL $\mathrm{m}^{-1}$ of NAA), 50\% and 57\% root emergence was recorded. This reduction in root emergence showed that IBA is better than NAA as it trigger early cell division and root primordia formation than NAA. The superiority of IBA over NAA in inducing rooting has been reported in several studies on Chrysanthemum morifolium (Nalini, 2012), Spilanthes calva (Razaq et al., 2013) and Saussurea costus (Sharma et al., 2018). Lowest root emergence percentage was recorded in treatment T2 (2 mgL ${ }^{-1}$ of IBA), this is because of basal callusing which interferes with root induction. As in vitro rooting is associated with basal callusing and intensity of which depends on concentration of the auxins (Arora \& Bhojwani, 1989). In present study, high concentration of IBA induces maximum rooting and reduction in concentration of IBA reduces rooting percentage whereas low concentration of NAA induces maximum rooting and high concentration suppressed the root emergence.

\section{Root length}

Statistical analysis after 3rd week of sub-culturing on rooting medium revealed that highest mean root length was recorded in treatment T4 ( $4 \mathrm{mgL}^{-1}$ of IBA) followed by treatments T5 (1 mgL $\mathrm{mb}^{-1}$ of NA) and T6 ( $2 \mathrm{mgL}^{-1}$ of NAA) (Table 2) (Figure 5). The reason for these differences in mean root length among auxins (IBA and NAA) is due to difference in physiological phenomenon which controls their uptake, transport, metabolization and subsequent gene activation (Ludwig-Muller, 2000). Cosgrove, (1999) discussed that cell elongation involves sequential changes in activity of enzymes and the enzymes required for cell enlargement processes are triggered by the auxin. IBA promotes root length by triggering the synthesis of enzymes involved in cell enlargement (Wada et al., (1998) and is possible reason for maximum mean root length in treatment T4. Treatment T7 ( $3 \mathrm{mgL}^{-1}$ of NAA) mean root length per shoot was $0.79 \mathrm{~cm}$. This inferior effect of NAA on root length is due to its high concentration as Taiz \& Zeiger, (2002) reported that root growth is strongly inhibited at high concentration of auxin because at high level it induce the production of ethylene, an inhibitor of root growth.

\section{Number of roots}

The effect of PGRs were observed in each treatments and statistical analysis after 3rd week of sub-culturing on rooting medium revealed that maximum mean number of roots was recorded in treatment T4 (4 mgL ${ }^{-1}$ of IBA) (Figure 6) (Table 2). This may be because of exogenously added IBA is converted into free IAA by $\beta$-oxidation and also the release of free IBA from IBA conjugates through hydrolysis (Epstein \& Ludwig-Muller, 1993). Both free IAA and IBA serve as a source of auxin during later stages of root development and may be the possible reason for maximum number of roots in treatment T4. Exogenous IBA enhanced not only endogenous level of IAA but also increase indole-3-acetyl-aspartic acid (IAAsp) that is required for normal growth of root stem cell

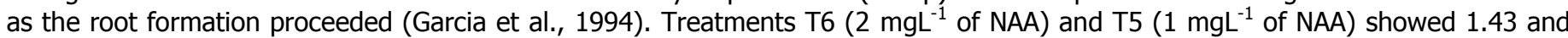
1.2 mean number of roots per shoot respectively. This inferior effect of NAA on the number of roots as compared to IBA is due to its more persistence nature which enables it to remain around the root tissues and block the formation of root stem cells (De Klerk

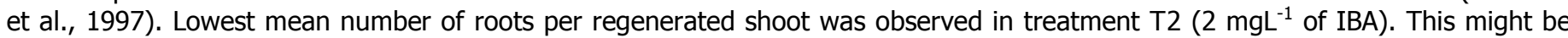
due to deficiency of free auxin required for the development of root meristemoids.

\section{Survival and death percentage}

On 3rd week of shifting of developed shoots on rooting medium, data regarding survival and death rate was recorded (Table 3). Highest survival rate was observed in treatments T4, T5 and T6, as these treatments possess well developed root and shoot system which is responsible for proper translocation and metabolism of nutrients from medium. Lowest survival rate was recorded in treatment T2, this might be because of poor rooting system which badly effect the growth of regenerated shoots. Treatment T1 (control) did not show any root emergence because of lack of auxin, so its survival rate was $0 \%$ and death rate was $100 \%$ (Figure 
7) as discussed by De Klerk, (2002) that the success of tissue culture depends on in vitro rooting of plantlets, without rooting plantlets will unable to withstand ex vitro condition.

\section{Hardening and acclimatization}

At the time of transplantation, data regarding Shoot growth of $5^{\text {th }}$ week old plantlets was recorded which showed a significant difference $(P \leq 0.05)$ among treatments (Table 4) (Figure 8). Highest shoot growth was recorded in treatment T4. This maximum shoot growth is because of well develop rooting system which help in absorption of nutrients from medium. The lowest shoot growth was recorded in treatment T2. This might be due to poor rooting system which retard shoot growth. In treatments T5 and T6 in which NAA was used, although have good shoot growth but show leaf necrosis which may be due to harmful secondary metabolites formed by NAA as reported by Ali et al., (2009) and Li et al., (2013). For hardening and acclimatization completely regenerated plantlets of various treatments were taken out of the culture tube (Figure 9) and washed gently with distill water to remove all the traces of medium adhere to the basal portion of the plantlets. After that, plantlets were transplanted in sterilized peat moss in green house (Figure 10).

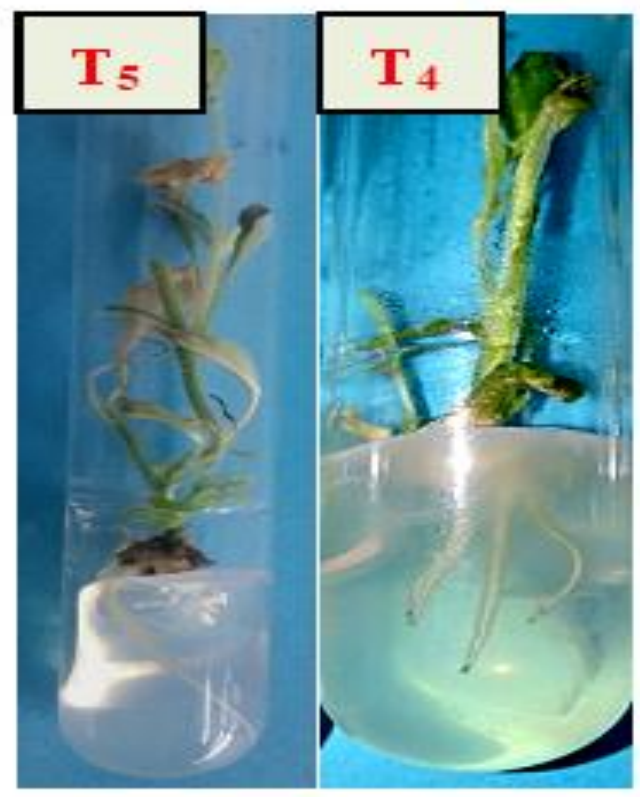

Figure 5. Treatments T4 and T5 showing root length after after 3rd week of sub-culturing on rooting medium.

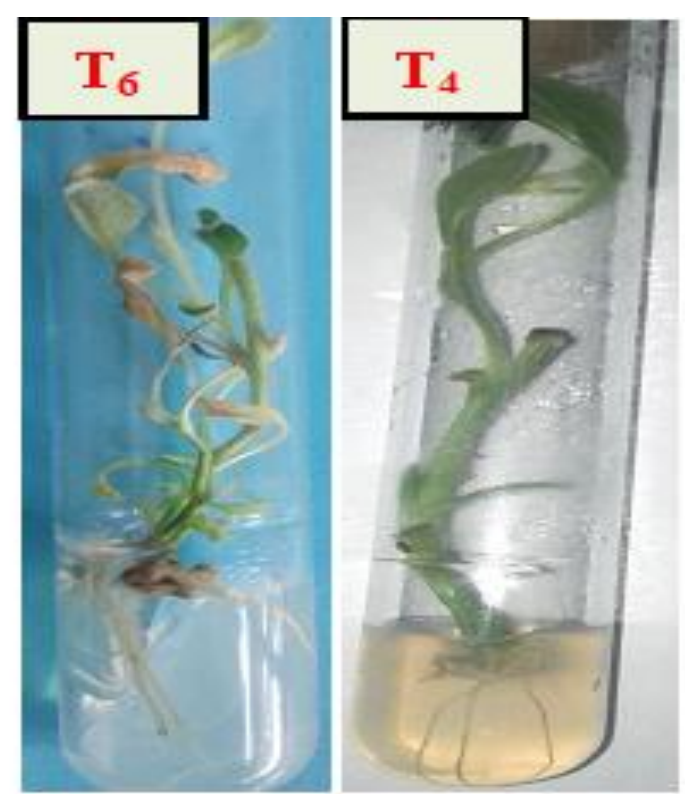

Figure 6. Treatments $\mathrm{T} 4$ and $\mathrm{T} 6$ showing number of roots 3rd week of sub-culturing on rooting medium.

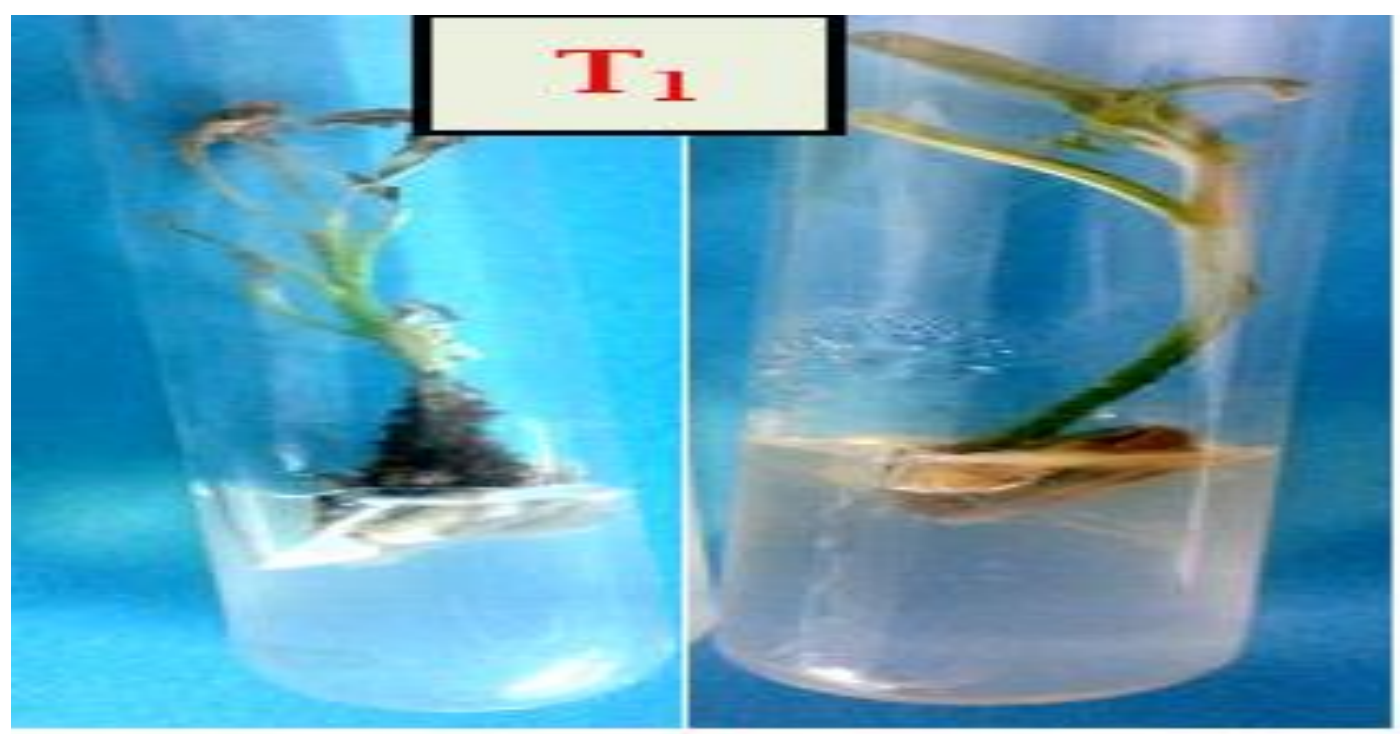

Figure 7. Treatment $\mathrm{T} 1$ showing plant death after shifting to rooting medium. 


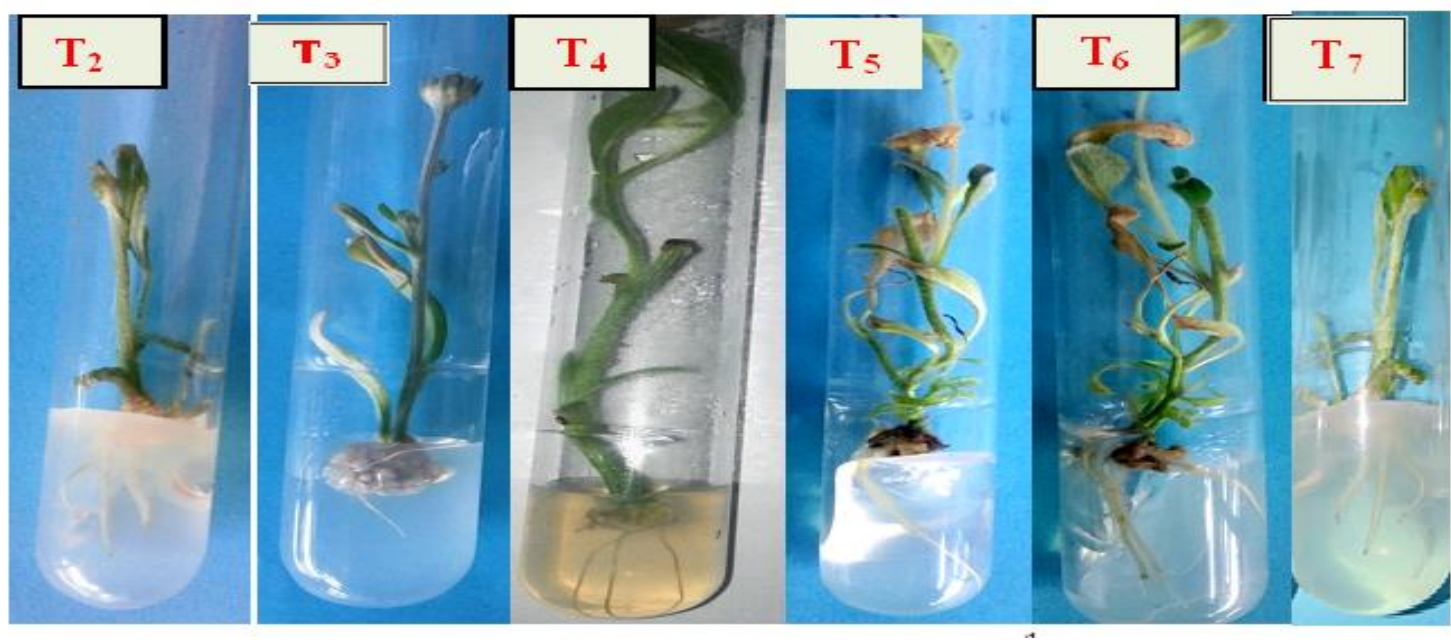

Figure 8. Treatments $\mathrm{T} 2, \mathrm{~T} 3, \mathrm{~T} 4, \mathrm{~T} 5, \mathrm{~T} 6$ and $\mathrm{T} 7$ showing growth rate after 5th week of culturing.

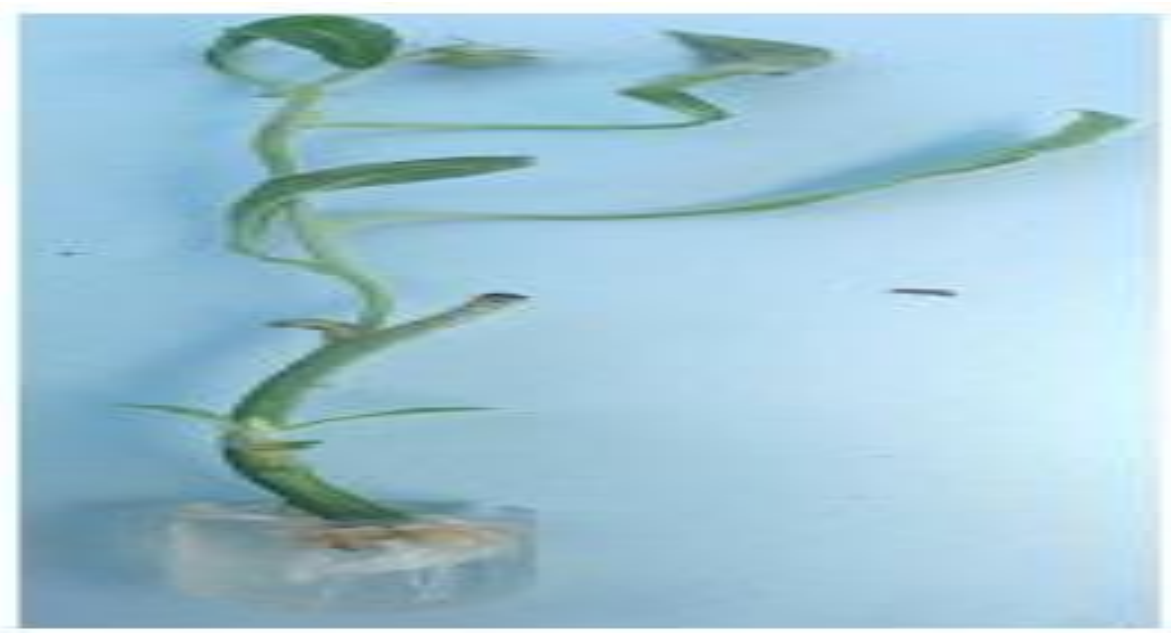

Figure 9. Regenerated plantlet with well-developed roots taken out of the culture tube.

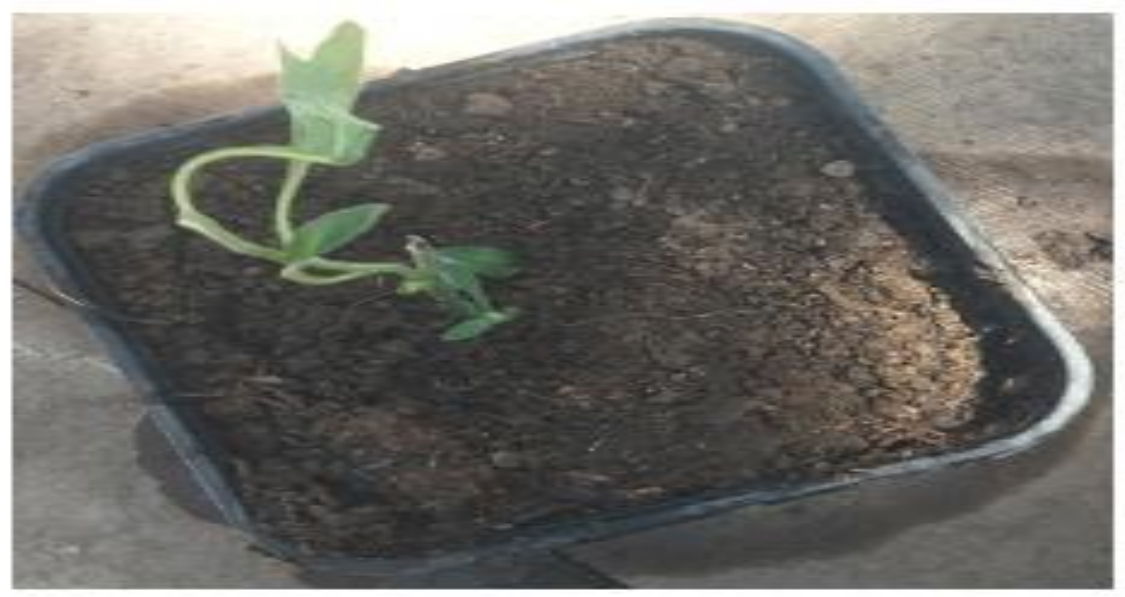

Figure 10. Hardening in green house.

\section{Conclusion and Recommendations}

Present research project concluded that overall status of Saussurea heteromalla in Galiyat areas of District Abbottabad is endangered and IBA at higher concentration is more effective for in vitro rooting and better shoot growth of Saussurea heteromalla whereas NAA also initiate rooting but at lower concentration. As present research project demonstrated Saussurea heteromalla to be endangered in Galiyat, therefore it has been recommended to stop over exploitation for medicinal purposes, to limit the interference of anthropogenic activities and livestock grazing; by doing so we can prevent it from extinction. This research work is the first attempt towards in vitro regeneration of Saussurea heteromalla, further research has been recommended for standardization of its successful in vitro regeneration by using other plant growth regulators (cytokinins). 


\section{References}

Al-Eissa, M. S. (2011). Effect of Gestation and Season on the Haematological and Biochemical Parameters in Domestic Rabbit (Oryctolagus cuniculus). British Biotechnology Journal, 1(1), 10-17.

Barnes, I.H., Bagnall, M.C., Browning, D.D., Thompson, S.A., Manning, G. \& Newell, D.G. (2007). Gamma-glutamyl transpeptidase has a role in the persistent colonization of the avian gut by Campylobacter jejuni. Microbial Pathogenesis, 43(5-6), 198-207. DOI: 10.1016/j.micpath.2007.05.007.

Botros, M., \& Sikaris, K. A. (2013). The deritis ratio: the test of time. The Clinical biochemist. Reviews, 34(3), 117-130. PMCID: PMC3866949

Çetin, N., Bekyürek, T., \& Çetin, E. (2009). Effects of Sex, Pregnancy and Season on some Haematological and Biochemical Blood Values in Angora Rabbits. Scandinavian Journal of Laboratory Animal Sciences, 36 (2), 155-162. doi.org/10.23675/sjlas.v36i2.180 Couch, C. E., Movius, M. A., Jolles, A. E., Gorman, M. E., Rigas, J. D., \& Beechler, B. R. (2017). Serum biochemistry panels in African buffalo: Defining reference intervals and assessing variability across season, age and sex. PLoS One, 12(5).

Daader, A., Al-Sagheer, A., Gabr, H., \& Abd El-Moniem, E. (2018). Alleviation of heat-stress-related physiological perturbations in growing rabbits using natural antioxidants. Spanish Journal of Agricultural Research, 16(3), e0610.

Dailidenok, V. N., \& Noreyko, A. Yu. (2014). Morphological and biochemical indicators of the blood of rabbits of different breeds bred in the Republic of Belarus. Bulletin Zootechnical science of Belarus, 49, 76-84. (in Russian)

Dontas, I. A., Marinou, K. A., Iliopoulos, D., Tsantila, N., Agrogiannis, G., Papalois, A., \& Karatzas, T. (2011). Changes of blood biochemistry in the rabbit animal model in atherosclerosis research; a time- or stress-effect. Lipids in health and disease, $10,139$.

Doumas, B. T., Biggs, H. G., Arends, R. L., \& Pinto, P. V. C. (1972). Determination of Serum Albumin. Standard Methods of Clinical Chemistry, 7, 175-188.

Duda, Y. (2019). Nonspecific reactivity of the rabbits organism when exposed to cysticercosis. Scientific Messenger of LNU of Veterinary Medicine and Biotechnologies. Series: Veterinary Sciences, 21(94), 132-135.

Duda, Yu. V., Prus, M. P., Kunieva, L. V., Shevchyk, R. S., \& Blyskavka, K. Yu. (2018). Protein metabolism and enzyme activity during spirochaetosis of rabbits. Mizhvidomchyi tematychnyi naukovyi zbirnyk: veterynarna medytsyna, Kharkiv, 104, 254-257. (in Ukrainian).

Enciklopediya klinicheskih laboratornyh testov (1997). Moscow. Labinform (in Russian).

Etim, N. N., Williams, M. E., Akpabio, U., \& Offiong, E. E. A. (2014). Haematological parameters and factors affecting their values. Agricultural Science, 2(1), 37-47.

Da Freitas, F. L.C., Yamamoto, B. L., de Freitas, W. L.C., Fagliari, J. J., de Almeida, K.S., Machado, R. Z., \& Machado, C. R. (2011). Systemic inflammatory response indicators in rabbits (Oryctolagus cuniculus) experimentally infected with sporulated oocysts of Eimeria stiedai (Apicomplexa: Eimeriidae). Revista Brasileira de Parasitologia Veterinária, 20(2), 121-126.

Gattani, A., Pathak A., Kumar, A., Mishra, V., \& Bhatia, J. S. (2016). Influence of season and sex on hemato-biochemical traits in adult turkeys under arid tropical environment. J Veterinary World, 9(5), 530-534. doi: 10,14202 / vetworld.2016.530-534

Gonchar A., Boyko A. \& Gavrish O. (2020). Modern trends in the development of rabbit breeding in Ukraine. Livestock today, 1, 7479

Gbore, F. A., \& Akele, O. (2010). Growth performance, haematology and serum Growth performance, haematology and serum biochemistry of female rabbits (biochemistry of female rabbits (Oryctolagus cuniculus ryctolagus cuniculus) fed dietary fumonisin. Vet. Arhiv, 80, 431-443.

Gromadzka-Ostrowska, J., \& Zalewska, B. (1985). Seasonal fluctuations in plasma protein fraction levels of chinchillas (Chinchilla laniger, M.). Comparative Biochemistry and Physiology Part A: Physiology, 80(2), 215-224.

Gumerov, V. G. (2015). Kliniko-biohimicheskie pokazateli krovi krolikov pri sovmestnom primenenii associirovannoj inaktivirovannoj vakciny s immunomoduljatorami. Uchenye zapiski Kazanskoj gosudarstvennoj akademii veterinarnoj mediciny im. N.Je. Baumana, 221, 56-59. (in Russian)

Guo, M., Wu, F., Hao, G., Qi, Q., Li, R., Li, N., Chai, T. (2017). Bacillus subtilis Improves Immunity and Disease Resistance in Rabbits. Frontiers in immunology, 8, 354.

Habeeb, A. A., Sharoud, M. N., Basuony, H. A., \& Michael, M. I. (2018). Effect of Environmental Climatic Conditions on levels of Some Hormones, Vitamins and Trace Elements in Blood and Seminal Plasma of Rabbits. Int J Biotechnol Recent Adv; 1(1), 18-23.

Hristev, H., Penkov, D., Hallak, A. K., Kirova, M., Baykov, B., \& Bliznakov, A. (2008). Serum protein changes in rabbits after chronic administration of lead and cadmium. Journal of Central European Agriculture, 9(1), 141-145.

Kamyshnikov, V.S. (2003). Textbook of kliniko-biohimicheskoy diagnostiki. Interpresservis, Ekoperspektiva, Belarus' (in Russian). Makarova, V. G. \& Makarova, M. N. (2013). Fiziologicheskie, biohimicheskie i biometricheskie pokazateli normy jeksperimental'nyh zhivotnyh. Sankt-Peterburg: LEMA. (in Russian)

Marai, I. F. M., Habeeb, A. A. M, \& Gad, A. E. (2008). Performance of New Zealand White and Californian male weaned rabbits in the subtropical environment of Egypt. Animal science Journal, 79(4), 472-480.

Marai, I. F. M., Habeeb, A. A. M, \& Gad, A. E. (2005). Tolerance of imported rabbits grown as meat animals to hot climate and saline drinking water in the subtropical environment of Egypt. Journals Animal Science, 81(1), 115-123.

Meineri, G., Giacobini, M. \& Forneris, G. (2017). Evaluation of physiological parameters of the plasma oxidative status in rabbits. Journal of Applied Animal Research, 45(1), 315-319.

Melillo, A. (2007). Rabbit Clinical Pathology. Journal of Exotic Pet Medicine, 16, 135-145. doi.org/10.1053/j.jepm.2007.06.002

Miyake, K., Miyake, N., Kondo, S., Tabe, Y., Ohsaka, A., \&Miida, T. (2009). Seasonal variation in liver function tests: a time-series analysis of outpatient data. Annals of Clinical Biochemistry, 46(5), 377-384.

Molina, E., González-Redondo, P., Moreno-Rojas, R., Montero-Quintero, K., Chirinos-Quintero, N., \& Sánchez-Urdaneta, A. (2017). Evaluation of haematological, serum biochemical and histopathological parameters of growing rabbits fed Amaranthus dubius. Journal of Animal Physiology and Animal Nutrition, 102(2), 525-533.

Nakyinsige, K., Sazili, A. Q., Aghwan, Z. A., Zulkifli, I., Goh, Y. M., \& Fatimah, A. B. (2013). Changes in Blood Constituents of Rabbits Subjected to Transportation under Hot, Humid Tropical Conditions. Asian-Australasian Journal of Animal Sciences, 26(6), 874-878.

Nowotny, A. (1979). Protein Determination by the Biuret Method. In: Basic Exercises in Immunochemistry. Springer, Berlin, Heidelberg, 168-169.

Okab, A.B., El-Banna, S.G., \& Koriem, A. A. (2008). Influence of environmental temperatures on some physiological and biochemical parameters of New-Zealand rabbit males. Slovak Journal of Animal Science, 41(1), 12-19. 
Ondruska, L., Rafay, J., Okab, A. B., Ayoub, M. A., Al-Haidary, A. A., Samara, E. M. \& Supuka, P. (2011). Influence of elevated ambient temperature upon some physiological measurements of New Zealand White rabbits. Veterinarni Medicina, 56(4), 180-186. Oohashi, E., Kimura, Y., \& Matsumoto, K. (2019). Pilot study on serum C-reactive protein in pet rabbits: clinical usefulness. Vet Rec Open, 6(1): e000272.

Özkan, C., Kaya, A., \& Akgül, Y.(2012). Normal values of haematological and some biochemical parameters in serum and urine of New Zealand White rabbits. World Rabbit Sci., 20, 253-259.

Plank, M. S., Boskovic, D. S., Tagge, E., Chrisler, J., Slater, L., Angeles, K. R., \& Angeles, D. M. (2011). An animal model for measuring the effect of common NICU procedures on ATP metabolism. Biological research for nursing, 13(3), $283-288$.

Prasad, K. (2008). Serum biochemical changes in rabbits on a regular diet with and without flax lignan complex following a highcholesterol diet. The International journal of angiology: official publication of the International College of Angiology, Inc, 17(1), 2732.

Reitman, S., \& Frankel, S. (1957). A Colorimetric Method for the Determination of Serum Glutamic Oxalacetic and Glutamic Pyruvic Transaminases, American Journal of Clinical Pathology, 28 (1), 56-63.

Salisu, I. B., Shahid, A. A., Ali,Q., Rao, A. Q., \& Husnain, T. (2018). Nutritional Assessment of Dietary Bt and Cp4EPSPS Proteins on the Serum Biochemical Changes of Rabbits at Different Developmental Stages. Frontiers in Nutrition, 5(49). doi: 10.3389/fnut.2018.00049

Shaobo Li, Zhifei He, Ying Hu \& Hongjun Li (2019) Shotgun proteomic analysis of protein profile changes in female rabbit meat: the effect of breed and age, Italian Journal of Animal Science, 18(1), 1335-1344,

Skabal, V. I. (2014). Funkcionuvannya ta tendenciyi rozvitku galuzej tvarinnictva v regionah. Ekonomichnij analiz , 75-80.

Suckow, V. A., Brammer, D.W., Rush, H. G., \& Chrisp, C. C. (2002). Biology and disease of rabbits. In Laboratory Animal Medicine. Fox, J. G., Anderson, L. C., Loew, F. M., \& Quimby, F. W. (Eds.). New York, NY: Academic Press.

Tietz, N.W. (1986). Textbook of Clinical Chemistry, W.B. Saunders Company, Philadelphia. Veterinary Manual. By S.E. Fielder. Serum Biochemical Reference Ranges.

Vlizlo, V. V., Fedoruk, R. S., \& Ratych, I. B. (2012). Laboratorni metody doslidzhen'u biologii', tvarynnyctvi ta veterynarnij medycyni: dovidnyk. L'viv: Spolom. (in Ukrainian).

Yaqub, L. S., Kawu, M. U.\& Ayo, J. O. (2013). Influence of reproductive cycle, sex, age and season on haematologic parameters in domestic animals. Journal of Cell Animal Biology, 7(4), 37-43.

\section{Citation:}

Mehreen, H., Zafar, J., Zishan, G. (2020). In vitro regeneration of Saussurea heteromalla (D. Don.) Hand-Mazz Using Auxins and Current Status in Galiyat Abbottabad. Ukrainian Journal of Ecology, 10(5), 1-7. 